\title{
Management of Collaboration between Schools and Communities in Play Group Management Efforts
}

\author{
Efrida Ita; Elisabeth Tantiana Ngura; Maria Fatima Landang \\ Sekolah Tinggi Keguruan dan Ilmu Pendidikan Citra Bakti \\ evoletelvo@gmail.com
}

Article received: January 2021; revised: April 2021 ; accepted: April 2021

DOI : 10.17977/um025v5i22021p113

\begin{abstract}
This study aims to describe: 1) the management of cooperation between the school and the community of West Nginamanu village in an effort to manage the childhood education in St. Hildegard Ize playgroup, and 2) the supporting and inhibiting factors in the management of cooperation between school and community in an effort to manage the childhood education in St. Hildegard Ize group play Wolomeze district, Ngada regency. This study used a qualitative approach and located in St. Hildegard Ize playgroup Wolomeze district. The subject of the study were the group play manager, parents, and village officials. Data collection was done through interviews, observation, and documentation. Data analysis used an interactive model from Miles and Huberman with its components, namely data reduction, data presentation, and conclusion drawing. The results show that 1) the cooperation management between the school and the members of the community in St. Hildegard Ize playgroup that seen from the planning, organizing, implementation, and controlling has been run well, but at the implementation stage it is still not optimal, 2) The hindering factors for cooperation between the school and the community namely the condition of parents' occupation, the improper building condition of St. Hildegard Ize playgroup, and the incapable teachers in communicating the children's development to the parents, whereas the supporting factors namely the parents' concern towards the early childhood education and the school's openness in receiving input from the parents.
\end{abstract}

Keyword: management, cooperation, playgroup

Early Childhood Education is a form of educational services provided to children from birth to six years by providing stimulation to all aspects of the child's development including physical and non-physical aspects (Isjoni, 2014: 20). This definition is in line with the Ministry of Education and Culture Regulation No. 137 of 2014 concerning PAUD National Standards states that Early Childhood Education is an effort to foster children from birth to six years of age through providing educational stimuli to assist physical and spiritual growth and development so that children have the readiness to enter further education.

Early childhood is the tempo to lay the first foundation in developing physical, cognitive, language, artistic, social-emotional, self-discipline, religious values, self-concept, and independence. This period will be very good if given an educational stimulus, and so that the educational stimulation is carried out appropriately, a professional educator is needed. These professional educators are called teachers. The teacher cannot play a role alone in the learning process without the presence of students. Students can also become benchmarks in achieving learning goals at school. Students take an active role in finding out for themselves the material based on their own experiences related to the material in learning activities.

The educational environment is divided into three parts, namely education in the family environment, the school environment, and the community environment. Basically, education does not have to be obtained only from formal education such as in the school environment, but non-formal education such as education in the family and community environment is also very supportive. In family environmental education, children are taught politeness when talking to parents. In education in the community, children are taught to be able to mingle with the community in order to create an attitude of mutual tolerance or mutual cooperation. 
The community as an external supporting factor for education needs to establish good cooperation with educational institutions so that the existence of these educational institutions gets a place and attention in the hearts of the community. The community as a vital supporter of the establishment of an educational institution needs to be given an understanding of the importance of education, especially early childhood education. However, the fact that there is still a group of people who do not support the existence of the PAUD education unit. As Yuniarti (2016: 8-9) affirms that cooperation between schools and communities is designed to form an educational ecosystem that can encourage the growth of character and a culture of achievement for all school members. To realize these hopes, cooperation is carried out by referring to the following principles: equal rights, equality, and mutual respect, the spirit of mutual cooperation and togetherness, complementary and strengthening, mutual care, mutual care, and compassion.

The general objective of this cooperation program aims to establish cooperation and harmony in educational programs in Early Childhood Education units, families, and communities as three education centers in building an educational ecosystem that is conducive to fostering the character and culture of achievement of students, while specifically the objectives Early Childhood Education unit cooperation program with families and communities to 1) strengthening partnerships between Early Childhood Education units, families, and communities in supporting learning environments that can develop children's full potential; 2) increasing the involvement of parents/guardians in supporting children's education at home and at school; and 3) increasing community participation in supporting educational programs in schools and in the community.

Based on the results of observations made in the St. Hildegard Ize playgroup in carrying out the learning process has obstacles, one of the obstacles is the lack of cooperation or community participation in efforts to manage the Kober because the community does not realize the importance of Early Childhood Education from an early age. In the St. Hildegard Ize playgroup, at the planning stage, cooperation and communication are carried out well between managers, teachers, committees, village governments, and parents or the local community by being involved in every form of activity. However, at the stage of implementing cooperation between the school and the community, efforts have been made, but the community is still fully busy with their main work and still maintains their respective arguments. Furthermore, at the organizing stage, the division of tasks was carried out with the assigned personnel. Therefore, the implementation of education, both government and private, must have the courage to take an attitude and insight that like it or not, schools must involve the local community, especially parents of students in the development of their education.

The existing resources in the community are optimally empowered, both human resources and financial resources for education. The existence of a good relationship between the school and parents and the community will be beneficial for the school, community, parents, and students themselves. Community participation functions to participate in maintaining, growing, enhancing, and developing national education.

The school's relationship with the community places more emphasis on meeting the needs of the community associated with schools. The implementation of community relations does not wait for community requests, but schools try to act and take the initiative to carry out various activities in order to create harmonious relationships and cooperation. According to research conducted by Iyer-Raniga, U. and Andamon, M.M (2016:116) harmonious cooperative relationships in a sustainable manner can create a harmonious educational environment between schools and the community.

According to Wiyani (2015: 120), management is a process of planning, organizing, directing, and supervising various efforts of organizational members and users of other organizational resources in order to achieve the stated organizational goals. Furthermore, the management process is carried out through management functions, according to Hamid (2012: 21), namely planning, organizing, leading, and controlling. From this explanation, it can be concluded that management is an effort of planning, organizing, implementing, and evaluating an organization manager in directing the performance of its members to achieve organizational goals by working together and making use of the various facilities it 
has. Therefore, in establishing cooperation between the school and the community, management is very important.

St. Hildegard Ize playgroup is one of the early childhood education platforms to guide and nurture children in preparation for education at the primary school level. As an educational institution, these playgroups need to be managed properly through a sequence of management processes to give birth to an educational unit capable of bringing students into character, quality, and achievement. One of the external supporting factors that must be built is close cooperation so that the school stands firmly in the community.

Based on the description above, a research was carried out with the title, "Management of Cooperation between Schools and the Village Community of West Nginamanu in an effort to manage St. Hildegard Ize playgroup, Wolomeze Subdistrict, Ngada Regency "with the formulation of the problem in this study are 1) How is the management of cooperation between schools and village communities in the efforts to manage St. Hildegard Ize playgroup? and 2) what are the factors inhibiting and supporting the management of cooperation between schools and village communities in efforts to manage the St. Hildegard Ize playgroup? With the formulation of the problem, the research objective is to describe: 1) the management of cooperation between schools and communities in the management of St. Hildegard Ize playgroup, and 2) inhibiting and supporting factors for the management of cooperation between the school and the community of the village of West Nginamanu in efforts to manage St. Hildegard Ize playgroup.

\section{METHODS}

This type of research used in this research is descriptive using a qualitative approach. Afrizal (2014: 13) defines a qualitative research method as a method of collecting social sciences that collects and analyzes data in the form of words (oral and written) and human actions and researchers do not try to calculate or quantify the qualitative data that has been obtained. Thus, the authors did not analyze the numbers.

This research was conducted in St. Hildegard Ize playgroup, Nginamanu Barat village, Wolomeze sub-district, Ngada district. The subjects in this study were the managers of the St. Hildegard Ize playgroup, village officials, and the community (parents). The object of research in this study is the management of cooperation between schools and the community of the village of West Nginamanu in an effort to manage Early Childhood Education. The selection of these informants is that these elements have a relationship and are related to each other in the implementation of education so that they can directly influence the management of cooperation between schools and communities in the St. Hildegard Ize playgroup.

Data collection methods used in the study were interviews, observation, and documentation. In this study, three techniques were used to collect data, which means that researchers used different data collection techniques to obtain data from the same source. The three techniques are in-depth interviews, observation, and documentation. Data analysis in this study used an interactive model analysis developed by Miles and Huberman (2009: 20) with steps including data collection, data reduction, data presentation, and conclusion drawing.

\section{RESULTS AND DISCUSSION}

\section{Management of Cooperation between Schools and Communities in the Effort to Manage St. Hildegard Ize Playgroup}

Manthe, M. and Smallwood, J. (2007) Cooperation is an important aspect in building partnerships between one party and another. Good cooperation creates a good relationship or partnership. Cooperation becomes the basis for strengthening and strengthening partnerships. Therefore, partnerships in the form of cooperation need to be built by parties who have similarities and different visions so that they can 
reach a mutual agreement through the cooperation carried out and need to be followed by a correct management process in the cooperation activity.

Management is the process of organizing and utilizing all resources within an organization in order to be efficient so as to realize the goals of the organization. As stated by Rohiat (2010: 14), management is managing the resources owned by schools/organizations which include people, money, methods, materials, machines, and marketing which are carried out systematically in a process. So, management as a means of achieving the goals of an institution is carried out through management functions including planning, organizing, implementing, and supervising.

1. Planning for Cooperation between Schools and Communities

Planning as an initial stage in the management process is very important because the right planning it can also provide the right direction in implementation activities (Ita, 2018: 47). This statement can be interpreted that before going through the stages in other management functions, it must be preceded by the planning stage.

Based on the research results, it is known that the cooperation between the people of the village of West Nginamanu and St. The Hildegard Ize playgroup has done well since the planning stage. In managing the playgroup, the school holds an internal joint meeting involving the school committee and the child's parents. This is done to find out and determine the schedule or time of the meeting between the school and the parents of students so that the planned agenda has clear objectives, the personnel involved in the implementation, and the objectives in the management of the playgroup.

Planning in implementing cooperation between schools and communities is carried out by the principal by involving various parties, namely teachers, committees, and parents of students. This is done by the school so that the program that is made not only belongs to the school but belongs to the community, is decided together so that in its implementation all school members provide support and take responsibility for the success of the program.

This is in line with his opinion Mujamil (2007: 186) states that there are several approaches to carrying out collaborative management activities between schools and communities, including involving parents in school programs that are social in nature, such as community service.

\section{Organizing Cooperation between Schools and Communities}

Organizing as a stage of division of duties and responsibilities to everyone in order to carry out the programs that have been determined together properly. Organizing is important so that the limited ability, willingness, time, and energy can be overcome in order to achieve the goals of the Institute. As stated by Wiyani (2017: 33), organizing is the process of dividing work into smaller tasks, assigning these tasks to people according to their abilities, allocating resources, and coordinating them in order to effectively achieve organizational goals.

Based on the results of the study, it is known that the task distribution process is carried out well between the school and the local community. Everyone gets the same portion of assignments according to their respective abilities and authorities, starting from the school leader (the head of St. Hildegard) and the head of the West Nginamanu village, the parents of the child to the community and made by a decree by the head of the playgroup.

\section{Implementation of Cooperation between Schools and Communities}

The planning stage is carried out to find out how and the process of implementation. Based on the research results, the implementation of cooperative activities from the planning that has been carried out has not been implemented optimally. It can be seen that some of the programs that have been agreed upon, have not been implemented according to planning and organization such as making school foundations and school fences attended by some communities, parents have not fully supported children such as taking children to school, and teachers have not communicated child development to people. old. The communication and cooperation that have been established have not been implemented properly during the implementation stage, causing delays in the implementation process for subsequent programs. This is a reference for achievement and unattainment in the management of St. Hildegard Ize playgroup 
which has an impact on the existence, sustainability and progress of these educational institutions for the next generation of local communities.

4. Supervision of Cooperation between Schools and Communities

This supervision is carried out to see the suitability between planning and implementation in the management effort of the St. Hildegard Ize playgroup so that the causes of ineffectiveness can be identified in order to take corrective action in the future. Supervision is carried out every week and month by the school manager, namely the principal. In addition to supervision by the principal, the community is also involved in supervision. Supervision is carried out by the community or parents of students in the form of a review to just see the condition and progress of the paper.

\section{Inhibiting and Supporting Factors of Cooperation between Schools and Communities in Efforts to Manage St. Hildegard Ize Playgroup}

According to Munoz, D.A., Queupil, J.P. and Fraser, P. (2016:416) building a network of cooperation has an important role to develop educational institutions. The process of managing an educational institution is not an easy thing like turning the palm of the hand. The management of these institutions requires special skills in managing and utilizing all the resources contained within the institution so that they can be optimized in order to achieve the goals of the institution. St. Hidegard Ize playgroup comes with a vision to help hone, guide, and educate children from an early age in order to optimize the growth and development of children as a future generation with strong characters that are inseparable from inhibiting and supporting factors in their management efforts.

Factors inhibiting cooperation between schools and communities in efforts to manage St. Hildegard Ize playgroup are as follows.

1. Parents' working conditions

Most of the parents' jobs at the St.Hildegard Ize playgroup as farmers are an obstacle for children to enter school in the playgroup. Parents fully hand over the child's education to the teacher at the school and leave the child to other family members or home caregivers. For example, when children are excited to go to school but their parents are busy with work that cannot be left behind. Some children have to miss school because parents are busy at work who cannot prepare and take their children to school.

\section{St. Hildegard Ize Playgroup building conditions that do not meet the requirements}

The building used today still belongs to the posyandu. This happened because there was no assistance from the government in the form of a building for the St. Hildegard Ize playgroup. However, the manager of the playgroup continues and remains eager to teach children in the building while trying to communicate with the government to pay more serious attention to the need for appropriate learning places for children.

3. Teachers are less able to communicate child development to parents

A teacher must be able to communicate well about child development to parents so that the meaning of the message to be conveyed can be well received. However, there are times when the teacher experiences difficulties in delivering the message, and this is the beginning of a problem between the teacher and parents because parents misinterpret the message from the teacher. All of this makes collaboration between teachers and parents impossible.

Supporting factors for cooperation between schools and communities in efforts to manage St. Hildegard Ize playgroup are as follows.

1. Parents' concern for early childhood education

Parents' concern for children's education makes parents always feel curious about their child's development. At St. Hildegard Ize playgroup, parents can directly meet the class teacher and talk about the development of their child. Based on the teacher's opinion, parents must be aware that the involvement of parents in children's education is very necessary because the involvement of parents in children's education can contribute a lot to the progress of children's education. 
2. The openness of the school in receiving input from parents

Schools are institutions entrusted with the responsibility of educating children by parents, but in operation, parents can be involved in the learning process because in addition to school children also get an education at home provided by parents so that the sustainability of programs carried out at school can be continued in the family environment.

\section{CONCLUSIONS AND SUGGESTIONS}

From the description, in the discussion, it can be concluded that: 1) the management of cooperation between schools and village communities in the St Hildegard Ize playgroup by implementing four management functions, namely: (1) planning. At St Hildegard Ize playgroup, planning is always carried out in any form of activity that involves managers, teachers, committees, village governments, and parents or the local community in order to establish good cooperation and communication, (2) organization. At St. Hildegard Ize playgroup, organizing is always both communication and cooperation with the village government and parents of students even though not all parents are involved because they are busy with personal work, (3) implementation. Implementation of cooperation has not been carried out optimally, (4) supervision. Supervision is carried out by the manager (principal) on a weekly and monthly basis and is always communicated if a problem occurs so that it can be immediately followed up. 2) Inhibiting factors in the management of cooperation between schools and village communities in efforts to manage Early Childhood Education at St. Hildegard Ize playgroup is the working conditions of the child's parents, the condition of the building that has not met the requirements, and the teacher is unable to communicate the child's development to the parents, while the supporting factors in implementing the management of cooperation between schools and village communities in efforts to manage Early Childhood Education at St. Hildegard Ize playgroup, namely parents' concern for early childhood education and the openness of schools in receiving input from parents

Some suggestions that can be conveyed based on the results of this research include: 1) For managers. Managers need to collaborate with parents of students, the local village government and be more active in conducting meetings in fostering a sense of belonging and community responsibility for the management of Early Childhood Education so that it is easier to collaborate with the community for the implementation of activities in the Kober. 2) For the village government. The village government needs to facilitate activities related to Early Childhood Education and pay attention to all the shortcomings that exist in the playgroup. 3) For parents. Parents need to maintain a cooperative relationship with the school and continue to provide the best support for the success of existing programs in the school and for advancing the school for the future of their children.

\section{REFERENCES}

Afrizal. (2014). Metode penelitian kualitatif sebuah upaya mendukung penggunaan penelitian kualitatif dalam berbagai disiplin ilmu. Jakarta: PT.Raja grafindo Persada.

Hamid, Mansyur Abdul. (2012). Pengantar Manajemen. Yogyakarta: PT. Nusa Indah.

Ita, Efrida. (2018). Manajemen pembelajaran pendidikan anak usia dini di TK Rutosoro Kecamatan Golewa Kabupaten Ngada Flores Nusa Tenggara Timur: Jurnal Dimensi Pendidikan dan Pembelajaran Universitas Muhammadiyah Ponorogo, Vol 6 No 1: Halaman 45-52. http://journal.umpo.ac.id/index.php/dimensi/ article/view/889 DOI : 10.24269/dpp.v6i1.889

Isjoni, H. 2014. Model Pembelajaran Anak Usia Dini. Bandung: Alfabeta.

Miles, Matthew B \& A Michael Huberman. (2009). Qualitative data analysis (terjemahan). Jakarta: UI Press.

Mujamil. (2007). Makna, konsep dan istilah administrasi dan manajemen pendidikan. https://alimzebua.wordpres. com Diakses pada tanggal 26 Juli 2020.

Permendikbud No 137 tahun 2014 tentang Standar Nasional Pendidikan Anak Usia Dini.

Rohiat. (2010). Manajemen sekolah: teori dasar dan praktikdilengkapi dengan contoh rencana strategis dan rencana operasional. Bandung: PT Refika Aditama. 
Yuniarti, dkk. (2016). Petunjuk teknis kemitraan satuan PAUD dengan keluarga dan masyarakat. Yogyakarta: Pustaka Belajar.

Wiyani, Novan Ardy. (2017). Manajemen PAUD berdaya saing. Yogyakarta: Penerbit Gava Medi

Iyer-Raniga, U. and Andamon, M.M. (2016), "Transformative learning: innovating sustainability education in built environment", International Journal of Sustainability in Higher Education, Vol. 17 No. 1, pp. 105-122. https://doi.org/10.1108/IJSHE-09-2014-0121

Manthe, M. and Smallwood, J. (2007), "The appropriateness of built environment tertiary education: Perspectives of academics and postgraduate students", Journal of Engineering, Design and Technology, Vol. 5 No. 2, pp. 102-119. https://doi.org/10.1108/17260530710833167

Munoz, D.A., Queupil, J.P. and Fraser, P. (2016), “Assessing collaboration networks in educational research: A co-authorship-based social network analysis approach", International Journal of Educational Management, Vol. 30 No. 3, pp. 416-436. https://doi.org/10.1108/IJEM-11-2014-0154 